\title{
Analytical Methods to Assess Financial Capacity in Face of Innovation Projects Risks
}

\author{
Tatyana Rogulenko ${ }^{1}$, Evgeniy Vladimirovich Orlov ${ }^{2}$, Oleg Alexandrovich Smolyakov ${ }^{1}$, \\ Anna Vladimirovna Bodiako ${ }^{3, *}$ and Svetlana Valeryevna Ponomareva 4 \\ 1 Department of Accounting, Audit and Taxation, Institute of Economics and Finance, State University of \\ Management, 109542 Moscow, Russia; tmguu@mail.ru (T.R.); smolykov_osa@mail.ru (O.A.S.) \\ 2 Research Institute of Managing the Digital Transformation of the Economy, State University of Management, \\ 109542 Moscow, Russia; bombardier63@yandex.ru \\ 3 Audit and Corporate Reporting Department, Faculty of Taxes, Audit and Business Analysis, \\ Financial University under the Government of the Russian Federation, 125993 Moscow, Russia \\ 4 Department of Audit and Internal Control, Faculty of Economics and Finance, St. Petersburg State University \\ of Economics, 191023 Saint-Petersburg, Russia; ponsvetlana@mail.ru \\ * Correspondence: anna.bodyako@inbox.ru
}

check for updates

Citation: Rogulenko, Tatyana, Evgeniy Vladimirovich Orlov, Oleg Alexandrovich Smolyakov, Anna Vladimirovna Bodiako, and Svetlana Valeryevna Ponomareva. 2021. Analytical Methods to Assess Financial Capacity in Face of Innovation Projects Risks. Risks 9: 171. https://doi.org/10.3390/ risks 9090171

Academic Editor: Mogens Steffensen

Received: 25 June 2021

Accepted: 29 August 2021

Published: 18 September 2021

Publisher's Note: MDPI stays neutral with regard to jurisdictional claims in published maps and institutional affiliations.

Copyright: (c) 2021 by the authors. Licensee MDPI, Basel, Switzerland. This article is an open access article distributed under the terms and conditions of the Creative Commons Attribution (CC BY) license (https:/ / creativecommons.org/licenses/by/ $4.0 /)$.
Abstract: This paper aims to analyze the most relevant methods to determine the financial capacity of innovation projects and identify potential ways of their improvement. The research helped to propose an alternative methodology to assess the financial capacity of innovation projects by charting an alternative balance with a minimum scope of data (annual balance sheet data, project term). The authors drew a conclusion concerning the critical role of choices on the methods applied to analyze the financial capacity of innovation projects in the context of different scales and terms of project jobs in an analyzed project and the need for the proposed alternative (estimate or expertise-based) assessment of financial capacity as well as the relevant risks associated with the implementation of the new financial capacity assessment system and the overall risks of the innovation project. These specifically concern the choices of the methods of attribution of indirect costs in innovation projects, composition and scope of criteria to distinguish business processes to manage these processes and constituent operations, the form of a matrix of correspondence for a set of costs by the stages of an innovation project (event-based matrix accounting) and the information model of the objective-based methods of managing an innovation project as an object.

Keywords: accounting; forecasting; costs; innovation; machine building; risks

\section{Introduction}

The role of management accounting increases significantly in the conditions of instability of the external market environment, which necessitates the use of a risk-based approach when building a management accounting system. Management accounting, in this context, is an ordered system for collecting, registering, summarizing and presenting information about the economic activities of an organization and its internal structural divisions necessary for making managerial decisions. A number of specific requirements are imposed on the information used in the management accounting system. They should be: (1) operational, formed on the principle of "the faster, the better"; (2) targeted, i.e., aimed at solving specific management tasks; (3) targeted, focused on a specific customer-manager and the tasks he solves; (4) sufficient, i.e., not superfluous, but quite sufficient for making appropriate decisions.

In line with the theoretical principle of interdependence, the processes of accounting, analysis and control should constitute an organic network as a comprehensive information analysis and control support system of management for any industry of the economy, including innovation. Such interdependence is not upheld in the practice of regulations 
governing accounting, analysis and control, as most of them are inconsistent or even contradictory. Such inconsistencies in regulations impair cost identification in innovation projects for analytical accounting and control purposes. These inconsistencies can be divided into two groups: conditional and actual. In this case, nonconformities related to such a feature of management accounting as a low degree of regulation, and a high degree of regulation in accounting can be attributed to conditional ones. The low degree of regulation in management accounting is firstly due to the fact that management accounting information is formed in various forms, which can be changed several times during the reporting period, and secondly, to the lack of need to transfer this information to external users and appropriate standardization. Accounting information, in turn, although it can be generated automatically and in a short time, unlike managerial information, cannot be used by a manager without an accounting education. Thus, two reports of the same content can be perceived by the manager as two documents that do not correspond to each other. Actual inconsistencies include cases when part of the business operations of accounting is not reflected in the reports generated within the framework of the management accounting system, for reasons of simplification or lack of sufficient time for the formation of the report. As a result of actual inconsistencies in the decision-making process, the manager deals with incorrect indicators of management reporting (basic financial indicators, such as margin profitability, one-time costs, etc.).

The assumption proposed by the authors about the increasing role of management accounting in the conditions of instability of the external market environment is confirmed by the indication that there is a need to balance the criteria of time, cost, quality and risk in conditions of uncertainty (Mahdiraji et al. 2021), as well as the fact that there are risks in the form of so-called "fake" innovators offering obviously unprofitable projects, mentioned in Gurtuev et al. (2020). An additional proof of the presence of indirect nonstandard risks associated with an unstable external environment is the statement about the high rate of change in the business environment, mentioned in Hock-Doepgen et al. (2021). In addition, the research results presented in the publications of Babenko et al. (2018), Rutkowska-Ziarko and Markowski (2020), Gutsalenko and Marchuk (2020), Yau-Yeung et al. (2020), Domnin and Martynenko (2019), Drakeman and Oraiopoulos (2020) and Hartwig and Mathews (2020) are analyzed below.

The authors' statement about the existence of the interdependence of accounting, analysis and control processes is confirmed by the statement about the presence of (Abu Afifa and Saleh 2021) statements on the relationship between the effectiveness of management accounting systems (MASE) and Enterprise Risk Management (ERM).

The authors' assumption about the interdependence and inconsistency in regulations that make it difficult to identify costs in innovative projects is confirmed by the results of a study of the IMA, COSO and ISO 31000 standards, given in Kose and Agdenis (2019). The issue of increasing risks due to the lack of accuracy of accounting and statistical information is indirectly confirmed by the mention of the need to use accounting information about the actions of suppliers, customers, etc., in Kose and Agdenis (2019).The development of accounting regulations is influenced by the subjective factor (i.e., financial interests of international organizations charting the Principles of the IFRS). Russian accounting standards focus more on the legal form of transactions, in contrast to international standards focusing rather on the economic side, which leaves more room for accountants' professional judgement of the essence of operations. This regulatory inconsistency where the same economic event is accounted for differently under Russian and international rules leads to accounting errors. This means there is no accuracy and precision of accounting and statistical information to rely on in innovation forecasting.

These effects of subjective factors can be regulated by the harmonization of RAS and IFRS. However, there remains an obstacle posed to precise forecasting of innovations by the objective factor, which is nearly impossible to regulate. Given that economic processes are cyclical, forecasting the upward trends of business processes in the corporate economy 
is an extremely challenging task. Forecasting innovation activities is also complicated due to the fact that it is driven by research.

This dependence of the cost component (financial capacity) of an innovation project on the effects of subjective and objective factors creates a challenge for the management to choose adequate methods of analysis to approach the ongoing and developing new projects. In this case, the risk forecasting methodology specified in GOST R 51901.7-2017/ISO/TR 31004:2013 and GOST R 58771-2019. (IEC 31010: 201, NEQ) was used in the case of the application of the method proposed in the study for assessing the financial capacity, taking into account the specifics of the implementation of the innovation project.

Research objectives:

The paper seeks to address the following objectives:

1. To analyze the range of the most relevant assessment methods to approach the financial capacity of an innovation project.

2. To analyze the applicable assessment methods to approach the financial capacity of an innovation project and find ways to improve them, taking into account the risks arising from the implementation of the proposed method of assessing the financial capacity, as well as the risks arising from the implementation of an innovative project in machine building.

\section{Literature Review}

Relevant publications of the international scientific community devoted to a topic close to our research topic can include research in the field of evaluation of the relationship between a management accounting system, risk management and company performance (Abu Afifa and Saleh 2021; Kose and Agdenis 2019; Robinson et al. 2018; Sokolova and Bondareva 2019; Uyar 2018). Taking into account the results of these studies, particularly those containing information on the possibility of using management accounting methods in the risk assessment process, the question of the possibility of using an alternative settlement balance for a period of $n$ years for these purposes remains unexplored. An attempt to fill this gap was made in our study.

The methodological aspects of developing models underscoring variations in items or elements of costs were described by many experts (Bodiako 2018; Terenteva and Khalizova 2019; Voronova 2014). As a rule, the focus of research has been on the analysis of prepared statements with almost no emphasis on the in-depth cost mechanisms. These processes are so industry-specific that it is difficult to conduct an adequate cost analysis of this type even with access to modern analytical tools. The study of the practical activities of enterprises (Za Chestnyi Biznes 2018; Za Chestnyi Biznes 2019a; Za Chestnyi Biznes 2019b) has shown that the current cost management system does not fully contribute to solving the problems of their optimization and the efficiency of enterprise management. The situation is unsatisfactory with the methodology of analysis, planning and cost incentives.

The analysis of articles on similar topics allows us to form the following main conclusions that the authors came to: (1) the effectiveness of "internal knowledge systems" designed for the analysis of possible internal and external risks (Hock-Doepgen et al. 2021); (2) the possibility of forming a model based on the Bayesian game, which allows eliminating the risks of concluding contracts with "fake innovators") (Gurtuev et al. 2020); (3) the conclusion that there are some shortcomings in the ISO, CSO and ISO 31000 standards that lead to inconsistency of management and accounting data (Kose and Agdenis 2019); (4) the processes of accounting, analysis and control should be interdependent as an organic network and a comprehensive information, analytical and control management support system for any branch of the economy, including innovation, as well as the possibility of reducing risks through the introduction of an ERM system (Abu Afifa and Saleh 2021).

The article by Babenko et al. (2018) proposes a method based on the construction of sets of reach zones taking into account risks. Based on its application, we proposed a solution to the discrete optimization problem using minimax, in which a complex problem 
of dynamic optimization of multi-level control, taking into account risks, is applied to the implementation of a finite sequence of one-step discrete optimization problems.

In the article by Rutkowska-Ziarko and Markowski (2020), the authors investigate the relationship of profitability coefficients, as well as the risks of performing the main economic indicators of the company and their relationship with the market value of shares, as well as investment risks, using research methods such as comparing one-factor risk and return ratios with two-factor ones estimated using average returns in transverse regressions.

The theses of Gutsalenko and Marchuk (2020) largely coincide with the theses of our article. In particular, it is said that risk minimization is impossible without timely and reliable information about changes in market conditions, which is provided by taking into account the facts of the economic situation. Accounting risks are defined as an integral part of business risks (Gutsalenko and Marchuk 2020). It is proved that in order to achieve effective management, control is one of the important functions in the management system, since it combines accounting, analysis, forecasting and regulation of the activities of enterprises.

In the article by Yau-Yeung et al. (2020), the authors consider the issues of implementation and advantages of cloud computing in various contexts in accounting practice in the context of studying the risks of cloud accounting systems and services in Australia.

Attention should be paid to the study by Domnin and Martynenko (2019), in which the authors consider the need to determine the relationship between uncertainty and accounting risk reflected in their cause-and-effect relationships. Such an approach allows us to assess the problems of an enterprise and identify the economic component of these problems, as well as the system of economic security of an economic entity.

In the article by Drakeman and Oraiopoulos (2020), the authors consider the influence of uncertainty conditions on risk assessment methods.

In the study by Hartwig and Mathews (2020), the issues of the quality of management decisions, as well as the impact of the degree of automation of risk assessment on this factor, particularly for state research centers and private manufacturing companies, are considered.

Research of the problem of production cost management is determined by a number of aspects:

- first, the reduction of production costs together with an increase in production volume is one of the main sources of profit at an enterprise;

- secondly, the share of costs per unit of currency of the volume of production is high;

- thirdly, in modern conditions, separate accounting and planning of variable and conditionally fixed costs are necessary, which is associated with their different role in profit formation due to the independence of the latter from the volume of production, which is also unstable in the studied conditions;

- $\quad$ fourth, the share of conditionally fixed costs per unit of currency of sales volume is high;

The paper by Panchenko and Abrakhmanov (2014) points out a definitive aspect of innovation projects, that is, "the lack of market figures and statistics to determine the parameters of financial modeling, such as market capacity, average market price and other parameters of demand". There is no established market for the innovative product ${ }^{1}$ for which the analysis and assessment are conducted (Panchenko and Abrakhmanov 2014). Accordingly, the choice of the method of cost analysis depends not only on corporate specifics (industry, technology specifics: labor intensity, energy intensity, material intensity, etc.) but also on macroeconomic factors. The analysis of practices of cost analysis has shown that the methods used are mostly focused on identifying actual/plan variance and the fundamental drivers in the company's innovation activities. Analysts' focus is on the advantages and disadvantages of cost classification methods. For example, Poliakov (2017) believes that "the principal difference between cost grouping by calculation items vs. cost grouping by economic elements is that the former includes complex items comprising elements that are diverse in terms of their economic essence, principles of 
attribution and origin, methods of attribution between product types and variance of production parameters". Information on costs according to these criteria would provide the basis for innovation cost management and substantiation of decision making across the stages of project design and implementation (Poliakov 2017). A variant of solving this problem at one of the enterprises participating in the study was the introduction of an additional staff unit-an accountant-analyst. In the planning process, the accountantanalyst takes part in the development of long-term plans by providing information. In particular, he is also responsible for the formation of data on the results of the past period, which may be needed when forecasting indicators. The accountant-analyst coordinates the development of short-term plans by all departments and ensures that these plans are closely interrelated. Then, he brings these plans together and submits the overall estimate to the top management for approval. For control and regulation, management accounting data is used, which are summarized in reports on the achieved results. An accountant-analyst plays an important role in the process of control and regulation, informing the manager about cases of deviations of certain production results from planned indicators.

Analysts (Atrill and McLaney 2018; Bragg 2019) find it more practicable to arrange analytical accounting and control information by financial responsibility centers. However, for some of the machine-building enterprises analyzed in this research in terms of their available public statistical data (specifically, Myasishchev Design Bureau, AO; Solinov Research Institute of Technical Glass, AO; Baranov Central Institute of Aviation Motors, Federal State Unitary Enterprise), no additional analytical information is available to summarize data on cost management at the company level. We used the above-mentioned methodology to chart an estimated balance applied in this case for assessments of the financial capacity of innovation projects in the analyzed four-year period (Table 1). In addition, the assumption was that the change of relation between balance sheet assets and liabilities during the innovation project period (under various scenarios of project budget) would only occur in two items, Intangible assets and Research and development results. The scope of additional analytical data is limited by the applicable accounting methodologies. Unresolved are the aspects of intellectual resources engaged in projects by the company (knowledge, professional skills, experience, project managers' team styles, etc.) and value returns on the use of new technologies, etc. Accordingly, the uncertainty and risks of budgeting and further implementation of innovation projects usually, with rare exceptions, reduce potential analysis to mere actual/plan analysis.

Table 1. Required information for the assessment of the present value of real options.

\begin{tabular}{ccc}
\hline Item & Reference & Note \\
\hline Base asset value & $\mathrm{S}$ & $\begin{array}{c}\text { Present value of cash flows generated at the current } \\
\text { level of investment in the project }\end{array}$ \\
$\begin{array}{c}\text { Option execution price } \\
\text { Required rate of return }\end{array}$ & $\mathrm{K}$ & $\begin{array}{c}\text { Initial costs of the project works } \\
\text { Risk-free rate (rate of public treasury bonds adjusted } \\
\text { for macroeconomic circumstances in the country) }\end{array}$ \\
\hline
\end{tabular}

Target reference costs calculated according to reference norms are conceptually different from normal costs under standard costing methods, as their level is determined based on internal corporate production parameters. Thus, derived costs are maintained for the whole reporting period as approved standards (budget items). Monthly cost analysis is conducted by comparison of actual vs. normal cost levels and identifying variances. Target costing ties target costs to market conditions, i.e., makes them externally oriented. This method is characterized by the constant enhancement of cost norms, as they are not limited by internal standards.

Thus, the practicability of target costing depends on whether there is a real possibility to assess the usefulness of each component for customers. For example, in target cost planning, the product is divided into several parts (e.g., an aircraft as a whole product is represented as referential cost-bearing elements, such as the body, the wing, the life-support 
system, the fuel system, the power engine, etc.). In practice, customer preferences are not always easily understood. An important condition for applying these methods is the company's capabilities to continuously monitor market conditions, conduct surveys of regular customers, apply reliability checks to their responses, etc.

Among the many above-mentioned systems of cost management, some analysts (Kaverina 2016) specifically prefer Kaizen costing as a "system oriented at success". Specifically, prof. Kaverina (2016) emphasizes that "Kaizen costing builds on the philosophy of gradual product and business process improvement by means of a cost-cutting policy". This method assumes the company would engage internal reserves without any meaningful external investment to adjust its operations or individual departments. In other words, the production program is tailored to meet a preset level of cost-cutting, which is gradually adjusted to the downside.

According to researchers, each of the above-mentioned systems of cost management can only be effective in certain economic conditions depending on company managers' and owners' objectives. Innovative companies integrating research and development, design or other innovation-oriented structures would not find Kaizen costing acceptable given the difficulty of assessment of intellectual costs and the challenges of normalization of basic labor cost in research activities. However, in terms of productivity of analysis, this method requires additional information from various sources (Figure 1).

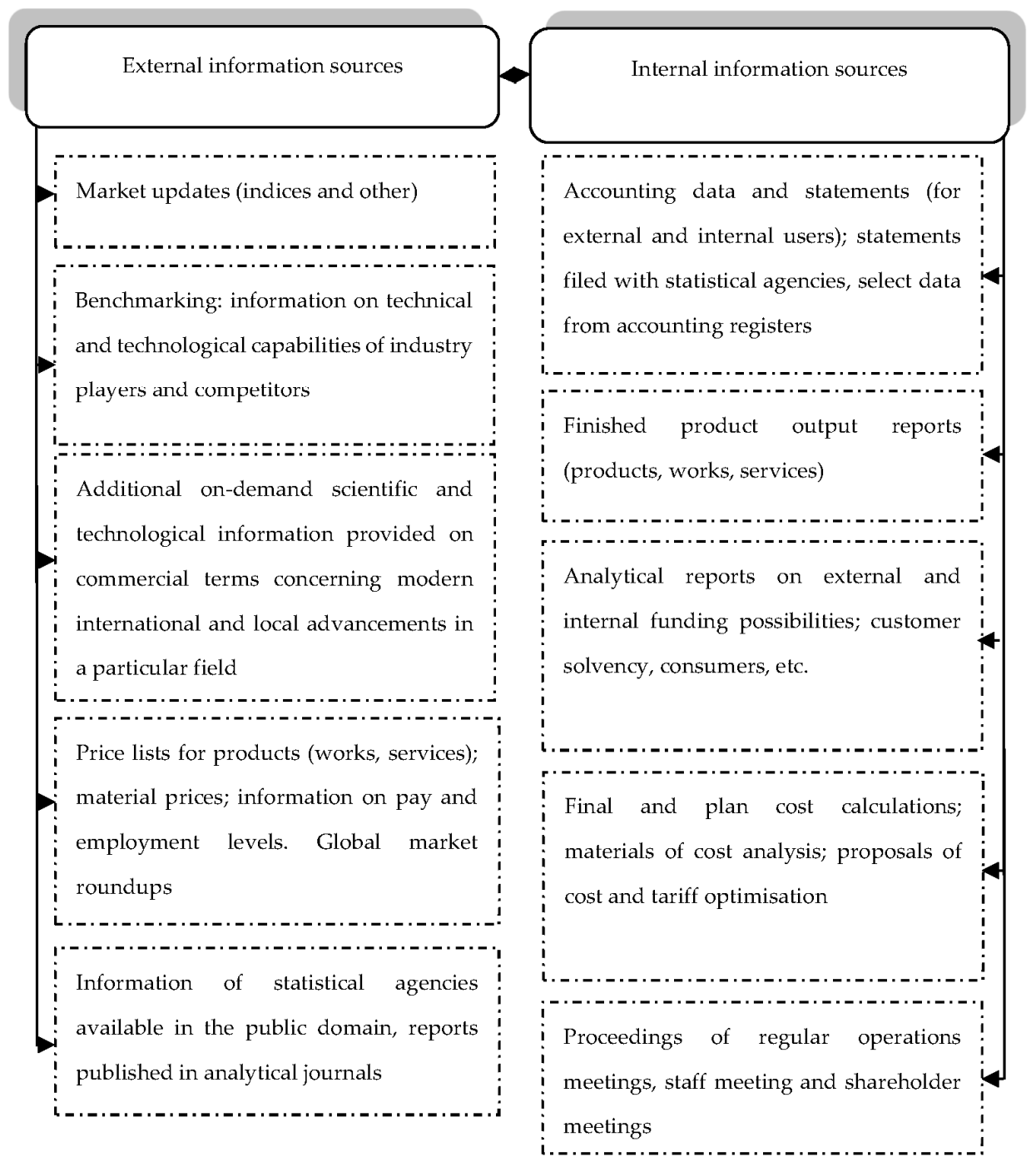

Figure 1. Information sources for CVP analysis (our interpretation). 
The resulting information pool (Figure 1) drawn from various sources systematized as necessary for decision making is usually tactical and represents a corporate secret. For this reason, specialist sources describing corporate practices of Cost-Volume-Profit, or CVP, analysis are insufficient for assessments of its practical effectiveness.

In conducting control analysis, different experts recommend distributing the analyzed functions of expanded reproduction factors by sectors, clusters, zones, etc. This approach is called "cluster analysis"2. Some analysts believe (Tiurin and Zuev 2014) that the methods of cluster analysis improve the information content of cost management results. The methods of cluster analysis include various cluster grouping approaches (sphere of business for objects from a territorial viewpoint: industry within a specific territory, economic subject or production factor: costs and output). Cluster analysis involves the distribution of a set of objects (situations) to subsets (called "clusters") to create a group of similar objects significantly distinctive from all other objects in other clusters. It is similar to the analysis of comparable objects. The specifics of clusterization relate to the methods of statistical data processing. This kind of multi-dimensional statistical procedure enables data collection in accordance with the project manager's requests for relevant information. Clusterization has been around as an analytical and statistical tool for long (Mandel 1988; Savinykh and Tsvetkov 2001). Some authors emphasize that there should be "embedded groups (clusters of various order)" when algorithms are classified between agglomerative and divisive. A taxonomy, or divisive hierarchical clusterization, aims to "filter information" (Asylbekov 2013; Zonova 2009, 2017). In Russian analytical practice, this method is in limited use and is rarely used in cost analysis for innovation projects.

Expert descriptions of the stages of cluster analysis show that this method is quite close to traditional cost classifications by specific stages of innovation projects (Figure 2), i.e., structuring costs by project stages and types of jobs can be described as clusterization by stages, types of jobs, management structures, responsible executives, etc.

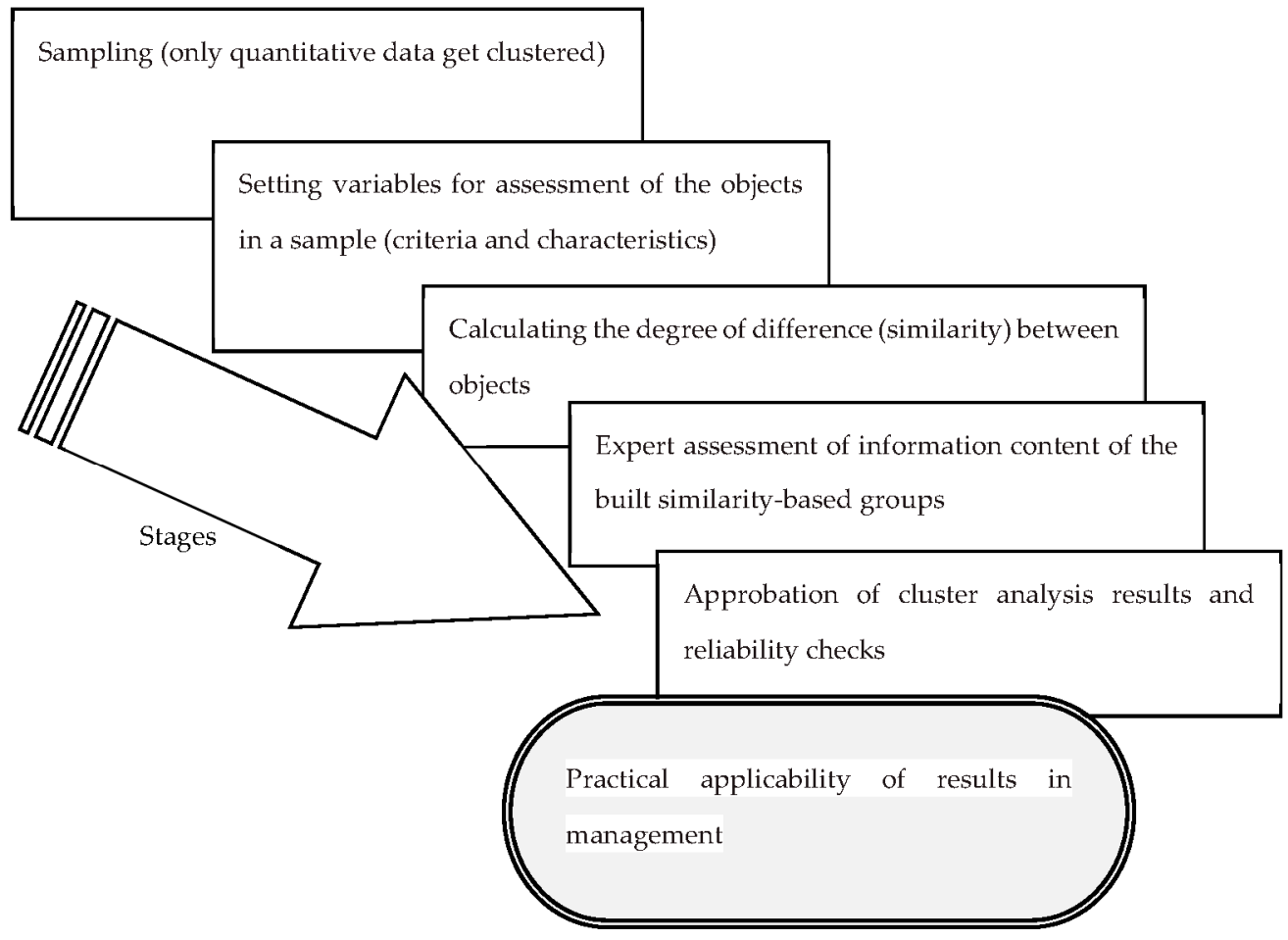

Figure 2. Stages of cluster analysis according to (Mizikovskii and Pivkin 2013).

A promising ground in research is applying the real options and fuzzy methods to the financial capacity problem (Rogova and Iarygin 2010). 
Even though the real options approach, compared to traditional methods, provides more accurate results in the assessment of projects implemented under high risks, it should be accompanied by fuzzy methods for more reliability. It would contribute to higher accuracy of assessment for venture investors and expand their available toolkit (Baranov et al. 2018; Bobylev 2010; Telekhov 2017).

A vast majority of research on the application of fuzzy methods in the analysis of the financial capacity of innovation projects is based on the findings of the doctoral thesis of Nedosekin (2003). The researcher developed the founding concepts of applying fuzzy methods to financial processes. Muzyko and Maslov (2015) and Muzyko (2011) propose fuzzy methods of analysis of the multi-criteria aspect of venture financing of investment projects with the use of real options. Real options constitute a tool to mitigate uncertainty in an innovation project by instituting an option based on income generated by the project in which managers have flexibility in the decision making concerning its further progress. Analysts divided these methods into two groups: based on the Black-Scholes model (Black and Scholes 1973) and applying the Cox-Ross-Rubinstein binomial tree (Cox et al. 1979) (Figure 3).
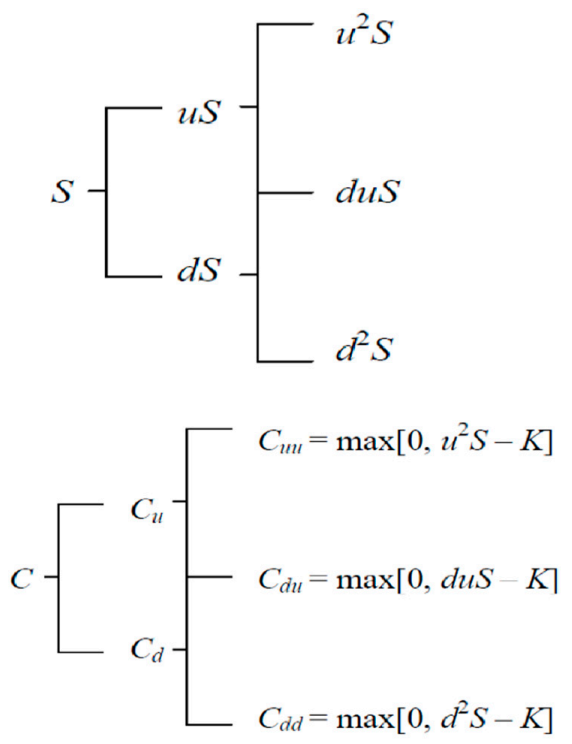

Figure 3. Algorithm of real options analysis under the binomial model according to (Cox et al. 1979).

Option execution is practicable if $\mathrm{S}>\mathrm{K}$. The algorithm of the binomial model is shown in Figure 3. The Black-Scholes model is based on continuous time tracking and is applicable primarily for financial options, which are bought and sold at any time in a standard liquid market (Table 1).

In Russia, there is no broad research body on the use of the real options method in venture financing of innovation projects in absence of domestic methodologies and due to the inapplicability of foreign concepts to the Russian practice. According to Muzyko and Maslov (2015), Geske's concept (Geske 1979) only partially suits the specifics of venture financing.

The proponents of the real options method believe that practical development of this analytical tool began after the publication of S. Myers' work "Finance Theory and Financial Strategy" (Myers 1987). The supporters of this method, McGrath (1997) and Rosenberger (2003), not only made a sound contribution to the development of the real options theory but also expanded its methodological and instrumental base. Russian scholars Bukhvalov $(2004,2006)$, Limitovskii (2017), Rogova and Iarygin (2010) proposed ways to adapt the real options method to suit Russian business and management traditions. Importantly, Bukhvalov $(2004,2006)$ pointed at the real options method as a means to enhance internal corporate financial control. 
In the digital space, the whole range of analytical tools is usually grouped between economic and statistical methods and economic and mathematical methods powered by advanced information technology, including the internet. Typical methods in each of the two groups are modified in use depending on the object of analysis and domain (social, finance, credit, insurance, etc.). Each method is oriented at a specific object. Accordingly, even greater specification of the methods depends on the industry, types of economic activities, the company's legal form ( $\mathrm{AO}$, federal unitary enterprise, etc.). Given that, it is hardly practicable to highlight specific groups of methods as "more functional". The choice of a specific method should be driven by its orientation at the analyzed subject.

Importantly, developing an innovative product poses a challenge to optimizing costs to generate additional economic value as it becomes available on the market. Various methods of value engineering (VE) and primarily the expanded and brief varieties are used to address the problems of functional optimization of product development structures and functional application of each business process (comparing product advantages by the functions, i.e., the potential value effect for the company) (Burganov 2015; Shcherbakov and Prikhodko 2003). In practice, the VE methodology is widely used in machine building, electrotechnical and electronics industry and innovation project management. Many analysts approach VE in two aspects: as an analysis (acknowledging the situation) and a corrective approach helping to manage costs as the innovation project is developed in real time (Mogilko 2019a, 2019b; Product and Service Design 2020; Ryzhova 2019). Research has shown that creative VE has no advantages at the design stage of a multi-functional object. Corrective VE is applied to already existing objects to optimize their functional and economic capabilities, which experts also view as organizational innovation. The cost transfer model (optimization of enhancement development functions by cost levels) recommended by D. Iu. Mogilko is only applicable in cases when there is a clear criterion for assigning objects to multifunctional objects. These characteristics are not cited in the publication (Mogilko 2019a, 2019b). However, the cost transfer model is mapped out as a graph reflecting the links between functions, costs and optimization outcomes, which presumably expands the scope of this method.

Information on the presence or absence of actual/plan variance by cost items or elements is derived from various models partially addressed by one of the authors of the paper (Orlov 2015a, 2015b): "standard cost"; "direct costing"; "just in time"; "value engineering" (VE); "strategic cost analysis" (SCA); "activity-based costing" (ABC), "Kaizen", "absorption cost", "target cost", etc. These authors argue in their papers that analysts set different requirements to information support of cost control analysis, e.g., level of detail, clear algorithm of analysis, industry-specific adjustments with regard to cost budgeting and control analysis of budget fulfilment (Chigarev 2019; Kogdenko 2019; Rogulenko and Smoliakov 2019). Cost breakdown between controllable and uncontrollable costs is usually included in budget fulfilment reports for each financial responsibility center. This enables a delineation of responsibility for each manager for easier assessment of their performance in controlling the unit's costs. To talk about the controllability of costs, it is necessary to explain that for management needs, costs are very often divided into responsibility centers. The Center for Financial Responsibility (CFR) is a structural unit within a company with its own function and financial budget and with its own responsible manager. Usually, when they talk about regulated costs, they assume that they can be influenced by the manager of a particular CFD. Regulated costs can include: (1) expenses from the write-off of technological defects (can be controlled by the head of the shop or production); (2) expenses from the write-off of raw materials that have lost their operational properties (can be controlled by the warehouse manager). Unregulated costs can include: (1) the costs of writing off an incorrigible defect as a result of using low-quality raw materials released from the warehouse (the head of production is not responsible for the procurement and storage of raw materials and therefore cannot affect its quality); the costs of spoiling raw materials in the warehouse as a result of the equipment that provides proper storage conditions 
failing due to a power outage in the warehouse (it is impossible to consider the warehouse manager guilty, because electricity supply is not within his competence).

Based on the above and practices of enterprises covered in this study, the following hypothesis can be stated: charting a balance as the most frequently used methodology of assessment of financial capacity and control analysis of an innovation project can be modified for the case where detailed annual calculation items are not available for charting a balance for $\mathrm{n}$ years, where $\mathrm{n}$ is the term of an innovation project.

\section{Methods}

According to the logic of research, the preliminary stage was concerned with a literature review in the research domain and related fields. Next, based on the resulting information from such a literature review and information on the analyzed enterprises (listed below) obtained from the public domain, the following research methods were considered: analysis, classification and aggregation, induction and synthesis, information modeling (development of information models). Specifically, the method of classification was used for choices of indirect cost attribution options in innovation projects (Figure 4) and determining the composition and scope of criteria to distinguish between business processes to manage them and their constituent operations (Figure 5). The method of aggregation allowed us to use the concept of a matrix of correspondence for specific accounts (Figure 6). The methods of induction and synthesis were used in charting an alternative estimated balance for the enterprise for $\mathrm{n}$ years (in this case, four years), in accordance with the project term, to assess potential business value effects (changes in asset value) under different budget fulfilment options (principal function of the balance) and provide an expert assessment of the project's financial capacity (auxiliary function of the balance) (Table 1). The method of information modeling was used in mapping out the information model of objective-based management of an innovation project as an object.

The risks associated with the use of the new methodology are not calculated separately in the companies that participated in the study. As a rule, they are taken into account in various budget scenarios "Pessimistic", "Basic" and "Optimistic", which are developed during the budgeting process. In this study, the authors suggest using a similar approach to assess such risks. In relation to assessing the risks associated with the assessment of the implementation of an innovative project, the authors recommend following the methodology set out in Table 2.

Table 2. Methodology for assessing the risks associated with the assessment of the implementation of an innovative project in accordance with Sokolova and Bondareva (2019).

\begin{tabular}{|c|c|c|c|c|}
\hline \multirow{2}{*}{ Project Objective } & \multicolumn{4}{|c|}{ Scale of Assessment of the Consequences of the Occurrence of Risks } \\
\hline & Low & Middle & High & Very High \\
\hline $\begin{array}{c}\text { Terms of } \\
\text { implementation }\end{array}$ & $\begin{array}{c}\text { Increase in the } \\
\text { implementation period } \\
\text { by } 5 \%\end{array}$ & $\begin{array}{c}\text { Increase in the } \\
\text { implementation period } \\
\text { by } 5-10 \%\end{array}$ & $\begin{array}{c}\text { Increase in the } \\
\text { implementation period } \\
\text { by } 10-20 \%\end{array}$ & $\begin{array}{c}\text { Increase in the } \\
\text { implementation period } \\
\text { by more than } 20 \%\end{array}$ \\
\hline Project costs & Cost increase by $10 \%$ & Cost growth by $10-20 \%$ & $\begin{array}{l}\text { The increase in costs by } \\
20-30 \%\end{array}$ & $\begin{array}{c}\text { Cost growth of more } \\
\text { than } 30 \%\end{array}$ \\
\hline $\begin{array}{l}\text { Quality of project } \\
\text { results }\end{array}$ & $\begin{array}{l}\text { It is shown only on the } \\
\text { main parameters of the } \\
\text { project. }\end{array}$ & $\begin{array}{l}\text { It is necessary to } \\
\text { coordinate with the } \\
\text { head of the } \\
\text { organization and the } \\
\text { sponsor of the project. }\end{array}$ & $\begin{array}{l}\text { The deterioration of the } \\
\text { quality of the project } \\
\text { will not be approved. }\end{array}$ & $\begin{array}{l}\text { The low quality of the } \\
\text { project calls into } \\
\text { question the possibility } \\
\text { of its implementation } \\
\text { as a whole. }\end{array}$ \\
\hline
\end{tabular}

The analysis of practices of the enterprises covered in the research showed that a requisite condition in a competitive setting is ensuring the enterprise has certificates of conformity under GOST ISO 9001-2011 and GOST R ISO 9001-2015. A specific feature of ISO 9001, specifically, is the process-based approach (process description of a business) 
(ISO 2015). Under the above-mentioned methodology, additional research was conducted to determine the possibility of running an activity-based cost analysis under the method ABC-ABB-ABM (Activity-based costing, Activity-based budgeting, Activity-based management). This method provides the collection and systematization of information on various economic items (including income and expenditure) by business processes and operations. The use of a "process-based method" in company management (ABC-ABB-ABM) according to ISO series 9001-2011 requires a delineation of business processes into three main groups: core, managerial and support processes. Moreover, tools based on ABC-ABB-ABM are integrated into specific accounting software and described in the respective sources (Ivlev and Popova 2007). This method remains a relevant path for a significant number of enterprises, including the three enterprises covered in this study (Myasishchev Design Bureau, AO; Solinov Research Institute of Technical Glass, AO; Baranov Central Institute of Aviation Motors, Federal State Unitary Enterprise). All the above-mentioned efforts rely on select elements of the concept of open innovation. In particular, (1) engaging external developers of certain machinery and units by setting the terms of reference, providing them to potential suppliers and conducting tenders for development and supplies; (2) creating interim working groups for innovation projects including both local and external experts.

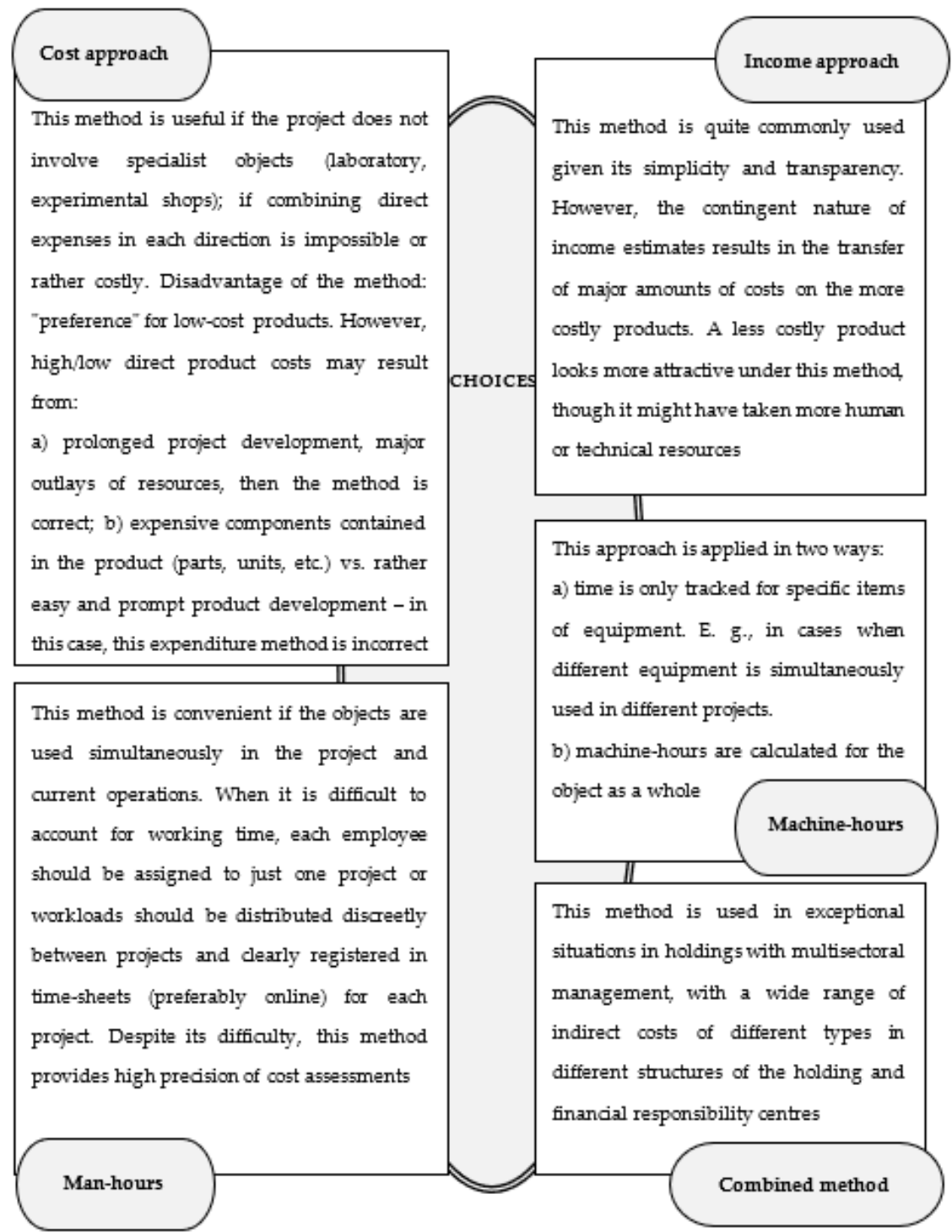

Figure 4. Options for choosing methods for allocating indirect costs in the implementation of innovative projects. 


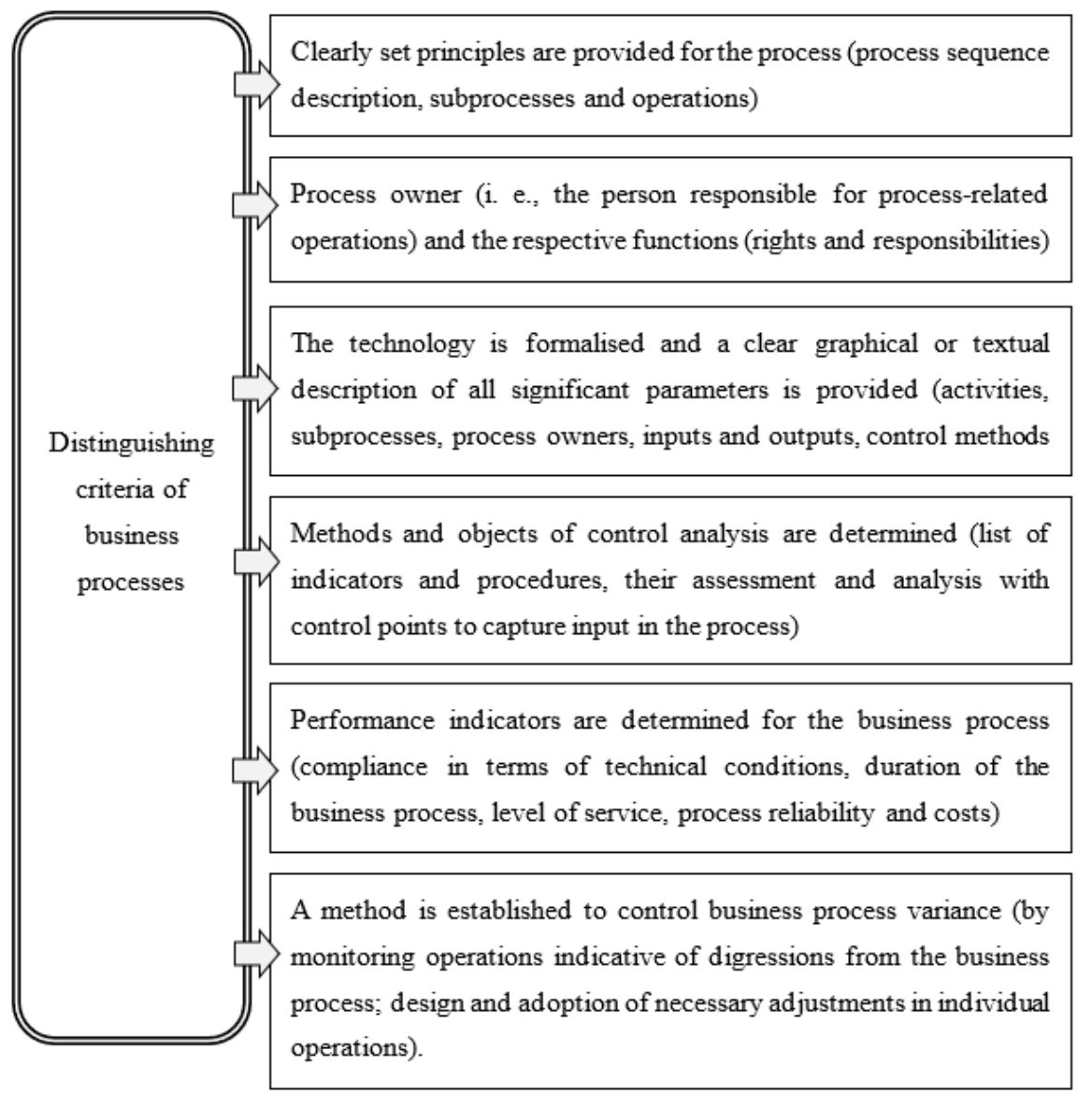

Figure 5. The composition and scope of criteria serving to distinguish between business processes for managing them, and the respective operations.

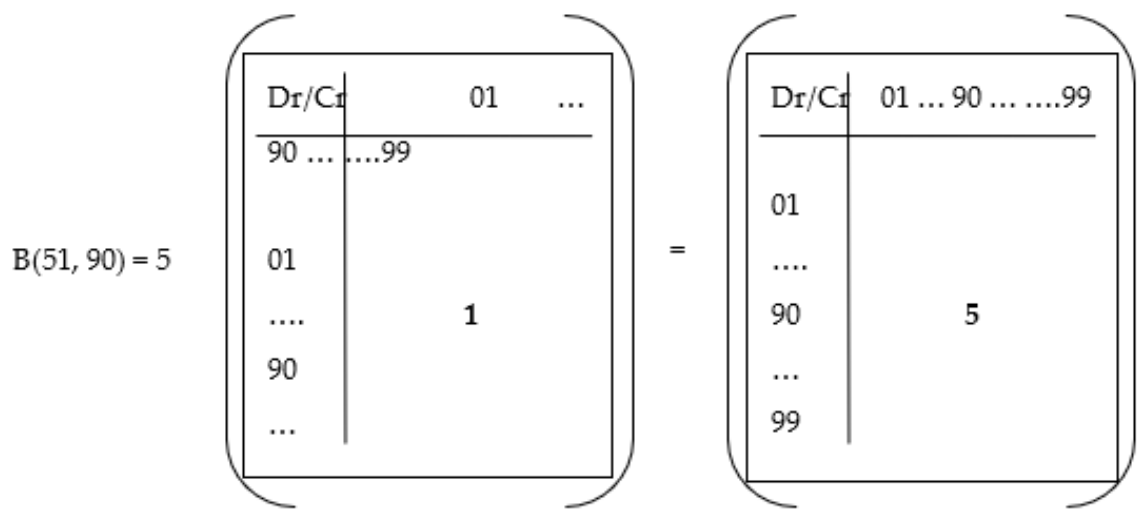

Figure 6. A matrix of correspondence $\mathrm{B}(51,90)=5$ lines of costs by stages of innovation project.

As mentioned above, the risks arising from the implementation of the methodology for assessing the financial capacity of innovative projects can be divided into two categories (in accordance with GOST R 51901.7-2017/ISO/TR 31004:2013 and GOST R 58771-2019. (IEC 31010: 201, NEQ)):

- $\quad$ risks associated with the use of a new methodology for assessing the financial capacity of the project;

- $\quad$ risks associated with the implementation of an innovative project.

\section{Results}

Let us look at each of these groups of risks in more detail. 
Since the methodology proposed by the authors for assessing financial capacity is an element of the budgeting system, it can be assumed that the risks that arise when using this system will be similar to the risks characteristic of the budgeting system. The estimated risks associated with the implementation of the new methodology are shown in Table 3.

Table 3. Types of risks that correspond to the situation of applying the new methodology for assessing financial capacity.

\begin{tabular}{lll}
\hline \multicolumn{1}{c}{ Type of Risk } & \multicolumn{1}{c}{ Risk Description } & \multicolumn{1}{c}{ Risk Hedging Methodology } \\
Cash flow deficit budget & $\begin{array}{l}\text { The deficit budget is not feasible, which } \\
\text { means that the functional budgets and } \\
\text { functional plans on the basis of which these } \\
\text { budgets are drawn up are unrealistic. }\end{array}$ & $\begin{array}{l}\text { To eliminate the budget deficit, you can } \\
\text { use the following actions: review of } \\
\text { financial flows, review of the production } \\
\text { program, taking a loan. }\end{array}$ \\
\hline Tse of actual accounting data & $\begin{array}{l}\text { The information provided in the accounting } \\
\text { statements cannot be used for budget } \\
\text { management for two main reasons. Firstly, it } \\
\text { is not operational, and secondly, it lacks the } \\
\text { necessary analytical representation, for } \\
\text { example, for financial responsibility centers. }\end{array}$ & $\begin{array}{l}\text { Planning and control should be carried } \\
\text { out only on the basis of management } \\
\text { accounting data. }\end{array}$ \\
\hline Overestimation of financial indicators & $\begin{array}{l}\text { There are cases when the departments } \\
\text { responsible for preparing budgets } \\
\text { deliberately overestimate the planned } \\
\text { indicators. }\end{array}$ & $\begin{array}{l}\text { Almost all departments of the enterprise } \\
\text { take part in budgeting, and the financial } \\
\text { service acts as a coordinator of this } \\
\text { process. }\end{array}$ \\
\hline $\begin{array}{l}\text { Incorrect calculation of the cash flow } \\
\text { deficit/surplus }\end{array}$ & $\begin{array}{l}\text { Often, when calculating the annual cash flow } \\
\text { budget, the total net cash flow is taken as the } \\
\text { budget deficit (or surplus) in each month. }\end{array}$ & $\begin{array}{l}\text { To estimate the deficit, it is necessary to } \\
\text { take into account not only the cash flow, } \\
\text { but also the cash balances at the } \\
\text { beginning of the period. }\end{array}$ \\
\hline
\end{tabular}

The risks associated with the implementation of an innovation project are usually hedged by applying methods of quantitative risk analysis of the innovation project, namely: sensitivity analysis (vulnerability) and scenario analysis and risk simulation using the Monte Carlo method.

Sensitivity analysis (vulnerability) occurs when each variable is changed "sequentially": only one of the variables changes its value (for example, by $10 \%$ ), on the basis of which a new value of the used criterion (for example, NPV or IRR) is recalculated.

It is necessary to emphasize the fact that sensitivity analysis is to some extent an expert method. In addition, this method does not analyze the relationship (correlation) between the variables being changed.

Scenario analysis is a development of the methodology for analyzing the sensitivity of an innovation project in the sense that the entire group of variables is subjected to a simultaneous consistent (realistic) change. The pessimistic variant (scenario) of a possible change in variables, the optimistic and the most probable variant are calculated. In accordance with these calculations, new values of the NPV and IRR criteria are determined. These indicators are compared with the baseline values, and the necessary recommendations are given.

The recommendations are based on a certain rule: even in an optimistic scenario, it is not possible to leave an innovative project for further consideration if the NPV of such a project is negative, and vice versa: a pessimistic scenario in the case of a positive NPV value allows the expert to judge the acceptability of this project despite the worst expectations.

Risk analysis using a Monte Carlo simulation is a combination of sensitivity analysis and scenario analysis techniques. This is a rather complex technique which has only a computer implementation. The result of this analysis is the probability distribution of the possible results of the innovation project (for example, the probability of obtaining NPV <0).

An analysis of conditions making it practicable to use ABC (in case of significant prevalence of overhead costs over direct costs, particularly, direct labor costs; in situations 
of production of a wide range of different products; in contexts with wide-ranging resources (overhead costs) involved in manufacturing of the product; in situations when the volume of overhead costs is not tied to the output but primarily depends on the number of operations or other factors) led us to compile the following list of criteria for classifying business processes adopted at the enterprise (Figure 5).

An alternative algorithm of costing helping to increase the information content of statements could integrate elements of event-based matrix accounting (Kolvakh 2000). Figure 6 represents a visualization of this matrix.

Models involving graphs and matrices in accounting and control analysis have recently been recommended by many analysts (Poliakov 2017; Porkhun 2011). According to A. Poliakov, innovation project managers need to operate the methods of reconciling production costs item-by-item with item-by-item analysis of the cost of sales; methods to capture costs shifting between items and changing their status (from costs to expenses, from assets to liabilities).

Some analysts believe that the event-based matrix methods of control analysis can be used for measuring managers' performance in cost-cutting efforts in innovative production if the marginal profitability rate misses the target (Horngren et al. 2011; Kuzmina 2016; Meerovich and Shragina 2018; Pchelkina and Kislov 2018; Troshin et al. 2016; Whitney 2015).

In Table 4, we present the results of charting an alternative balance for the enterprise for $n$ years (in this case, four years), in accordance with the project term, to assess potential business value effects (changes in asset value) under different budget fulfilment options as proposed in the research hypothesis.

Table 4. Estimated alternative balance for a term of four years (project term).

\begin{tabular}{|c|c|c|c|c|c|c|}
\hline \multirow{2}{*}{$\begin{array}{c}\text { Balance Sheet } \\
\text { Items }\end{array}$} & \multicolumn{5}{|c|}{ Myasishchev Design Bureau, AO } & \multirow{2}{*}{$\begin{array}{l}\text { Total for the } \\
\text { Period }\end{array}$} \\
\hline & 2018 & 2017 & 2016 & 2015 & 2014 & \\
\hline ASSETS, rubles & $3,259,049,000$ & - & - & $1,998,028,000$ & $2,156,577,000$ & $7,413,654,000$ \\
\hline Intangible assets & 0 & - & - & 0 & 0 & 0 \\
\hline $\begin{array}{l}\text { Research and } \\
\text { development } \\
\text { results }\end{array}$ & 0 & - & - & 0 & 0 & 0 \\
\hline Other & $3,259,049,000$ & - & - & $1,998,028,000$ & $2,156,577,000$ & $7,413,654,000$ \\
\hline $\begin{array}{l}\text { LIABILITIES, } \\
\text { rubles }\end{array}$ & $3,259,049,000$ & - & - & $1,998,028,000$ & $2,156,577,000$ & $7,413,654,000$ \\
\hline Source & \multicolumn{5}{|c|}{ (Za Chestnyi Biznes 2019a) } & \multirow{3}{*}{$\begin{array}{l}\text { Total for the } \\
\text { Period }\end{array}$} \\
\hline \multirow{2}{*}{$\begin{array}{c}\text { Balance Sheet } \\
\text { Items }\end{array}$} & \multicolumn{5}{|c|}{ Solinov Research Institute of Technical Glass, AO } & \\
\hline & 2018 & 2017 & 2016 & 2015 & 2014 & \\
\hline ASSETS, rubles & $1,018,147,000$ & - & - & $793,400,000$ & $811,226,000$ & $2,622,773,000$ \\
\hline Intangible assets & $111,074,000$ & - & - & $348,533,000$ & $375,438,000$ & $835,045,000$ \\
\hline $\begin{array}{l}\text { Research and } \\
\text { development } \\
\text { results }\end{array}$ & $8,448,000$ & - & - & 249,000 & 499,000 & $9,196,000$ \\
\hline Other & $898,625,000$ & - & - & $444,618,000$ & $435,289,000$ & $1,778,532,000$ \\
\hline $\begin{array}{l}\text { LIABILITIES, } \\
\text { rubles }\end{array}$ & $1,018,147,000$ & - & - & $793,400,000$ & $811,226,000$ & $2,622,773,000$ \\
\hline Source & \multicolumn{5}{|c|}{ (Za Chestnyi Biznes 2018) } & \\
\hline
\end{tabular}


Table 4. Cont.

\begin{tabular}{|c|c|c|c|c|c|c|}
\hline \multirow{2}{*}{$\begin{array}{c}\text { Balance Sheet } \\
\text { Items }\end{array}$} & \multicolumn{5}{|c|}{ Baranov Central Institute of Aviation Motors, Federal State Unitary Enterprise } & \multirow{2}{*}{$\begin{array}{l}\text { Total for the } \\
\text { Period }\end{array}$} \\
\hline & 2018 & 2017 & 2016 & 2015 & 2014 & \\
\hline ASSETS, rubles & $7,124,752,000$ & $6,911,460,000$ & $6,672,843,000$ & $6,689,163,000$ & - & $27,398,218,000$ \\
\hline Intangible assets & $12,591,000$ & $7,133,000$ & 710,000 & $1,160,00$ & - & $21,594,000$ \\
\hline $\begin{array}{l}\text { Research and } \\
\text { development } \\
\text { results }\end{array}$ & 0 & 0 & 0 & & - & 0 \\
\hline Other & $7,112,161,000$ & $6,904,327,000$ & $6,672,133,000$ & $6,688,003,000$ & - & $27,376,624,000$ \\
\hline $\begin{array}{l}\text { LIABILITIES, } \\
\text { rubles }\end{array}$ & $7,124,752,000$ & $6,911,460,000$ & $6,672,843,000$ & $6,689,163,000$ & - & $27,398,218,000$ \\
\hline Source & \multicolumn{5}{|c|}{ (Za Chestnyi Biznes 2019b) } & \\
\hline
\end{tabular}

The "Other" section of Table 4 includes balance sheet items such as: intangible assets, research and development results, intangible search assets and tangible search assets.

Amid the wide adoption of the objective-based method in managing innovations and fulfilment of its algorithms, such an algorithm was developed in this research, with adjustments for innovation project management (Figure 7).

This algorithm is applicable for innovator companies and beyond. The algorithm of the objective-based method is applicable for any manufacturing company conducting research and development operations and engaging experts from universities, industry research institutions, etc.

Analytical methods are used inseparably from the methods of cost control. This research adopts the term "control analysis", which in practice refers to the combination of methods of analysis and internal control and audits. The following sequence is proposed for such control analysis:

(1) preparation of the timeline of control analysis of costs (with the list of planned stages, volumes and planned costs by stages, periods and business units);

(2) constant monitoring of job progress and control analysis of actual costs as per accounting registers at the location of origin;

(3) constant identification of actual/plan variance by financial responsibility centers and isolation of divergence from adopted norms at the company level and industry level;

(4) analysis of the causes of such variance and decisions of the managers of the financial responsibility center to mitigate such causes unless they are associated with external factors (inflation, etc.). Corrections following control analysis can potentially occur at any stage of the project where the underlying cause is an internal subjective factor (managers' flaws);

(5) communications with top management concerning the observed misalignments (at least monthly) for taking prompt corrective steps.

In the analyzed companies, the control analysis function is overseen by the deputy director of finance or economic advisor to the general director. 


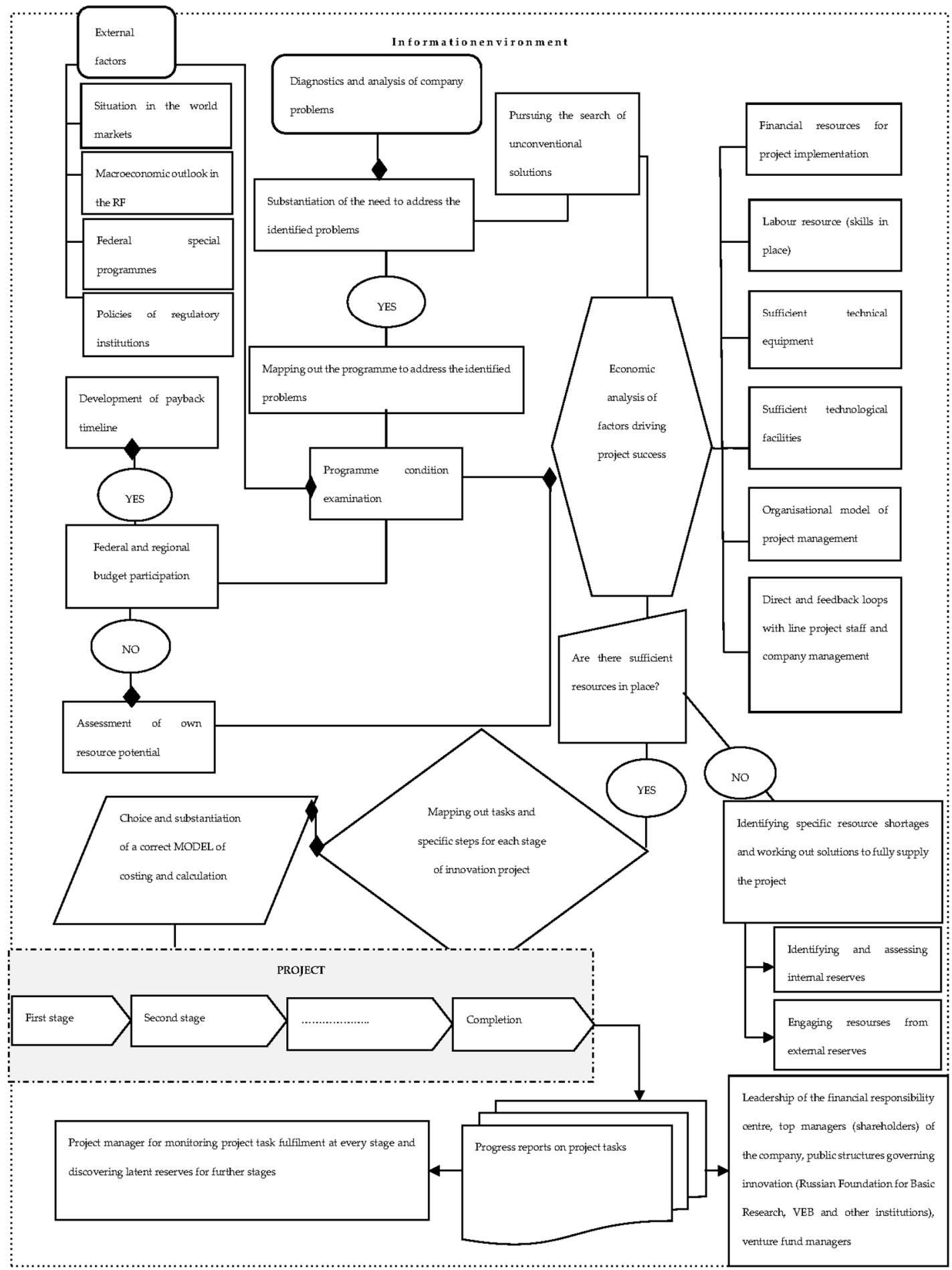

Figure 7. Objective-based management of an innovation project as an object.

The manager in charge can also oversee accounting, statistics, planning department and special control groups. The control analysis group operates with and is responsible for the objects and processes it oversees during the whole period of project implementation. The control analysis group interacts with the top project managers and is represented at critical meetings. The foundation of effective control analysis of costs is periodic audits of cost-to-expense transfer, i.e., audits of accounts (external financial and internal managerial statements). The research shows that procedures of internal audits in most companies are piecemeal, and methodological guidelines are a formality at best. Combining the 
principles and methods of control analysis of costs helps develop multiple scenarios of business project implementation. This kind of optionality of forecasts taking into account the objectives and changes of factors affecting them can galvanize investments in the area of innovation activities least accessible for forecasting, i.e., research. For machine building in 2018, the respective figures of "R\&D costs", "change of costs vs. 2008" and "costs to revenues ratio (\%)" stood at 5285 million USD, 3.1\% and 5.1\%, respectively. Accordingly, companies' outlays on research, development and transfer of new products and technologies have remained low. Data from the Expert RA agency show that the average rate of R\&D spending to revenues among major Russian companies equaled $0.75 \%$ in 2009, which is just above a third of the same figure for companies in the USA and Japan. In Russia, the highest innovation activity levels are associated with companies of the military-industrial complex, aircraft building and car manufacturing, however, the share of spending on R\&D is minor at about $3-4 \%$ of the total production costs. This lagging behind in terms of innovation is one of the reasons why managers try to find new methods to manage costs to maintain competitiveness.

\section{Discussion}

Let us consider the findings of this research in the context of similar works on this subject we analyzed above in the section of Literature review.

The conclusions obtained by the authors, particularly the statement about the prospect of using the developed method of assessing the financial capacity of the project by constructing a four-year settlement balance, are confirmed by the conclusions about the effectiveness of using "internal knowledge systems" for risk assessment purposes (Hock-Doepgen et al. 2021).

The authors' conclusions about the possibility of using models of correlation matrices and graphs are similar to the conclusions given in (Gurtuev et al. 2020). In particular, the authors claim the possibility of using mathematical tools similar in complexity and their "sufficiency" to solve the problem of numerical risk assessment of various nature.

The conclusions about the presence of inconsistencies in the RAS and IFRS standards obtained by the authors confirm the existence of a tendency towards discrepancies in management and accounting data in the process of using regulatory documentation mentioned by Kose and Agdenis (2019), despite the fact that in the two cases under consideration, different types of standards were analyzed.

The authors' conclusions about the interdependence of accounting, analysis and control processes are confirmed by the conclusions obtained on this issue in Abu Afifa and Saleh (2021).

A method for constructing sets of reach zones taking into account risks, proposed by Babenko et al. (2018) can be used as an addition to the method of assessing financial capacity by constructing a four-year settlement balance when verifying possible risks of implementing an innovative project, but it cannot replace it due to the different theoretical and mathematical bases of the proposed methods.

It can be assumed that the use of the method of assessing financial capacity by constructing a four-year settlement balance, in particular the risks of additional costs that are taken into account in the budgeting process, can be used to verify the list of the main economic indicators of the company considered by Rutkowska-Ziarko and Markowski (2020).

Some theoretical points proposed by Gutsalenko and Marchuk (2020) can supplement the list of theses that are prerequisites for using the methodology for assessing the financial capacity of an innovative project proposed by the authors. In particular, it is about considering control as a management function, and internal control (audit), which ensures the effectiveness of the control function of accounting, as a subsystem of accounting.

The automation issues discussed by Yau-Yeung et al. (2020) can be used in the continuation of the study of the assessment of financial capacity, as well as the risks of additional costs that are taken into account in the budgeting process. 
In our work, we did not consider such parameters as economic security. However, Domnin and Martynenko (2019) come to similar conclusions on the issues of eliminating the negative impact on the economic security system of an economic entity, but on issues of regulatory regulation of accounting and ensuring the completeness and reliability of accounting (financial) reporting indicators, as well as the completeness of reflecting the facts of economic life in accounting. In addition, the intersection of the research methods used-general scientific and applied research methods for studying external and internal factors of accounting risks-should be noted.

The authors of our article are similar to Drakeman and Oraiopoulos (2020) in their conclusions that the current conditions of the world economy are a "zone of uncertainty", especially when implementing an innovative project.

The research results of Hartwig and Mathews (2020) as well as the results of Yau-Yeung et al. (2020) can be used in the continuation of the study of the risk analysis methodology proposed by the authors of our article. The special value of the results obtained by Hartwig and Mathews (2020) is information about the features of risk assessment by state scientific centers, the number of which is quite large in the region under consideration.

The choices of indirect cost attribution methods for innovation projects presented in Figure 4 leave no possibility of such attribution if specialized entities are involved (laboratories, experimental shops), which are objects typical for experimental production, a principal participant of innovation projects. In other cases, the proposed options provide complete attribution of all indirect costs involved in the implementation of an innovation project. Moreover, this methodology is universal irrespective of the entity's organization structure, which is not the case for many other methodologies analyzed above from works by other authors.

An important aspect in terms of the composition and scope of criteria serving to distinguish between business processes for managing them and their constituent operations (see Figure 5) is that they specifically take into account the settings of an innovation project different from projects with low degrees of novelty. In particular, such settings include the complete formalization of the technology with graphical and textual descriptions of all significant parameters in place-in contrast to simplified descriptions of projects with low degrees of novelty.

As to the matrix of correspondence in Figure 6, the main difference of the described accounting algorithm compared to previous research is the proposition of a specific algorithm for accounts 51 Settlements and 90 Sales vs. only general principles of event-based matrix accounting in similar studies without any proven applicability for innovation projects.

The information model of the objective-based method of managing an innovation project rendering as an object (Figure 7) is universal and aligned with the practices of Russian enterprises in the current context, thus, it can be implemented at minimum costs at any enterprise considered in this study and similar to them in terms of activity and scope of operations. The potential application of the principles of the objective-based method described in similar works by other authors bears the risks of adaptation.

In contrast to other similar concepts, the proposed method of charting an estimated balance (Table 4) offers the possibility to calculate the project's financial capacity in situations of absence of "internal" balance sheet data and for project terms of more than one year. The limitations for the use of this type of estimated balance include the impossibility to assess the financial capacity of short-cycle innovation projects (shorter than one year).

\section{Conclusions}

We conclude that the choice of analytical methods to assess the financial capacity of an innovation project depends on the scale and term of project operation, which creates the need for our proposed alternative. In a situation when a company simultaneously pursues several innovation projects, it is practicable that costs are distributed and attributed to each of them, including administrative costs, salary and compensations, social insurance payments for administration, rent, maintenance costs on administrative offices, office costs, 
etc. When there is only one project and the technical part is outsourced with limited inhouse engagement within one or two business units, e.g., the IT and finance departments, only the respective categories of costs are to be distributed. In situations when individual structures are not engaged in projects, their respective maintenance costs are not distributed and are covered independently of the costs of project operations.

Given that the job-order method of overhead costing, in contrast to $\mathrm{ABC}$ costing, relies on the use of labor costs as an indicator while ignoring other factors such as the quality of equipment and novelty of technology, the choice of methods to analyze the multifactor influence on costs arguably requires establishing differences between costs and their affiliation with business processes. For that, we propose the use of various choices as to the method of attribution of indirect costs for innovation projects, criteria for distinguishing business processes, elements of event-based matrix accounting and the information model of the objective-based methods of managing innovation projects as an object. With regard to the possible risks that arise when using the system of assessing the financial capacity of the project proposed by the authors, it can be assumed that they will mainly be similar to the risks characteristic of the budgeting system.

As a result of the analysis of the most frequently used modern methods of analyzing the financial capacity of an innovative project, or indicators similar to the financial capacity indicator, the authors came to the conclusion that the method of assessment by constructing the settlement balance has not been studied yet, but has significant prospects, in particular due to the possibility of using the data of the settlement balance in the management accounting system when assessing possible risks of implementing an innovative project.

As a result of the analysis of the most frequently used modern methods of analyzing the financial capacity of an innovative project, or indicators similar to the financial capacity indicator, the authors came to the conclusion that the method of assessment by constructing the alternative balance has not been studied yet, but has significant prospects, in particular due to the possibility of using the data of the settlement balance in the management accounting system when assessing possible risks of implementing an innovative project. The result of the study was the construction of a four-year estimated alternative balance for the three enterprises that took part in the study. This calculation balance allowed to separate the "standard" cost items from the innovative ones (section "Other" includes balance sheet items such as: intangible assets, research and development results, intangible search assets and tangible search assets) and thereby assess the possible risks in the event of an unsuccessful implementation of an innovative project. Note that the "Others" section of the asset includes two main items "Other current assets" and "Other non-current assets". They, in turn, have the following structure: Other current assets include raw materials, materials and other similar values, costs in work-in-progress (circulation costs), finished products, goods for resale and shipped goods. Other non-current assets include expenses related to incomplete $R \& D$, expenses for the repair of fixed assets, advances issued for the construction of buildings, incomplete capital investments, etc. In particular, the cost items in the "Other" section can be evaluated in accordance with the methodology recommended by the authors for assessing the risks of implementing an innovative project, as well as the most common methods for assessing the risks of implementing the budget "Pessimistic", "Basic" and "Optimistic".

Author Contributions: All authors contributed equally. All authors have read and agreed to the published version of the manuscript.

Funding: The reported study was funded by the Russian Foundation for Basic Research (RFBR), project number 19-310-90001.

Institutional Review Board Statement: Not applicable.

Informed Consent Statement: Not applicable.

Data Availability Statement: The data are available on request from the corresponding author.

Conflicts of Interest: The authors declare no conflict of interests. 


\section{Notes}

1 In this paper, product refers to a product, service or intellectual property.

2 Cluster analysis is a multi-dimensional statistical procedure involving data collection on a set of objects [source: electronic resource: https: / /biznes-prost.ru/analiz-klasternyj.html] (accessed on 10 September 2021).

\section{References}

Abu Afifa, Malik Muneer, and Isam Saleh. 2021. Management accounting systems effectiveness, perceived environmental uncertainty and enterprise risk management: Evidence from Jordan. Journal of Accounting \& Organizational Change. ahead-of-print. [CrossRef]

Asylbekov, A. P. 2013. Singulyarnye Finansy [Singularity Finance]. In International Research and Practical Con-Ference on the 50th Anniversary of the Kazakh Ryskulov Economic University. Edited by S. Tamenova. Almaty: Ekonomika.

Atrill, P., and E. McLaney. 2018. Finansovyi Menedzhment i Upravlencheskii Uchet Dlya Rukovoditelei i Biznesmenov [Financial Management for Decision Makers]. Moscow: Alpina.

Babenko, Vitalina, Nataliya Chebanova, Natalia Ryzhikova, Serhii Rudenko, and Nataliia Birchenko. 2018. Research into the process of multi-level management of enterprise production activities with taking risks into consideration. Eastern-European Journal of Enterprise Technologies 1: 4-12. [CrossRef]

Baranov, A. O., E. I. Muzyko, and V. N. Pavlov. 2018. Otsenka Effektivnosti Innovatsionnykh Proektov s Ispolzovaniem Optsionnogo i NechetkoMnozhestvennogo Metodov [Performance Analysis of Innovation Projects with the Use of Options and Fuzzy Methods]. Novosibirsk: Institute of Economics and Industrial Engineering, Siberian Branch of the Russian Academy of Sciences.

Black, Fischer, and Myron Scholes. 1973. The Pricing of Options and Corporate Liabilities. Journal of Political Economy 81: 637-54. [CrossRef]

Bobylev, G. V. 2010. Ekonomicheskaya Otsenka Innovatsionnykh Proektov s Primeneniem Metoda Realnykh Optsionov [Economic Assessment of in-Novation Projects with the Use of Real Options Method]. Available online: http://economy-lib.com/disser/33 0288/a?\#?page=1 (accessed on 10 September 2021).

Bodiako, A. V. 2018. Uchetno-Analiticheskoe i Kontrolnoe Obespechenie Upravleniya Innovatsionnym Razvitiem Ekonomicheskogo Subekta [Accounting, Analytical and Control Support of Innovation Management of an Economic Entity]. Moscow: KnoRus.

Bragg, S. M. 2019. Accounting for Managers: Third Edition: A Business Decision Guide. Centennial: Accounting Tools.

Bukhvalov, A. V. 2004. Realnye Optsiony v Menedzhmente: Klassifikatsiya i Prilozheniya [Using Real Options in Management: Classi-Fication and Applications]. Rossiiskii Zhurnal Menedzhmenta 2: 27-56.

Bukhvalov, A. V. 2006. Realny Li Realnye Optsiony? [Are Real Options Real?]. Rossiiskii Zhurnal Menedzhmenta 3: 77-86.

Burganov, R. A. 2015. Funktsionalno-Stoimostnyi Analiz (Kratkii Kurs Lektsii) [Value Engineering (Short Lecture Course)]. Kazan: Kazan State Power Engineering University.

Chigarev, G. G. 2019. Finansovyi Menedzhment Kak Nauka i Iskusstvo Upravleniya Finansami [Financial Management as a Science and Art of Finance]. Vestnik Voronezhskogo Gosudarstvennogo Universiteta 1: 69-73.

Cox, John C., Stephen A. Ross, and Mark Rubinstein. 1979. Option Pricing: A Simplified Approach. Journal of Financial Economics 7: 229-63. [CrossRef]

Domnin, A. D., and O. V. Martynenko. 2019. Management of the economic subject and minimization of accounting risks. Scientific Journal NRU ITMO. Series "Economics and Environmental Management" 1: 112-18. [CrossRef]

Drakeman, Donald, and Nektarios Oraiopoulos. 2020. The Risk of De-Risking Innovation: Optimal R\&D Strategies in Ambiguous Environments. California Management Review 62: 42-63. [CrossRef]

Geske, Robert. 1979. The Valuation of Compound Options. Journal of Financial Economics 7: 63-81. [CrossRef]

Gurtuev, Alim, Elena Derkach, Salima Makhosheva, and Zaur Ivanov. 2020. A Bayesian approach to investment in innovation projects with the presence of fake innovators. Heliyon 6: E05603. [CrossRef] [PubMed]

Gutsalenko, L. V., and U. O. Marchuk. 2020. The Influence of Accounting Risks on the Quality of Information. Theoretical and Applied Issues of Economics 1: 163-72. [CrossRef]

Hartwig, Stephanie, and Scott Mathews. 2020. Innovation Project Risk Analytics: A Preliminary Finding: Use risk analytics for new product development for high-risk innovation projects. Research Technology Management 63: 19-23. [CrossRef]

Hock-Doepgen, Marianne, Thomas Clauss, Sascha Kraus, and Cheng-Feng Cheng. 2021. Knowledge management capabilities and organizational risk-taking for business model innovation in SMEs. Journal of Business Research 130: 683-97. [CrossRef]

Horngren, C., S. Datar, and M. Rajan. 2011. Cost Accounting: A Managerial Emphasis. New York: Prentice Hall Inc.

ISO. 2015. The Process Approach in ISO 9001:2015. Available online: https://www.iso.org/files/live/sites/isoorg/files/archive/pdf/ en/iso9001-2015-process-appr.pdf (accessed on 10 September 2021).

Ivlev, V. A., and T. V. Popova. 2007. ABC/ABM/ABB-Metody i Sistemy [ABC/ABM/ABB-Methods and Systems], 2nd ed. Moscow: 1C-Publishing.

Kaverina, O. D. 2016. Upravlencheskii Uchet [Management Accounting]: Textbook and Practicum for Academic Bachelor Programmes, 3rd ed. Moscow: Urait Publishing House.

Kogdenko, V. G. 2019. Upravlenie Finansami i Riskami [Managing Finance and Risks]. Moscow: UNITY Publishing House. 
Kolvakh, O. I. 2000. Situatsionno-Matrichnaya Bukhgalteriya Kak Odno Iz Sredstv Razvitiya Teorii Ucheta v Usloviyakh Sovremennykh Programmno-Informatsionnykh Tekhnologii [Event-Based Matrix Accounting as a Means of Development of Accounting Theorie in the Context of Modern So. Audit i Finansovyi Analiz 3: 24-40.

Kose, T., and S. Agdenis. 2019. The Role of Management Accounting in Risk Management. Muhasebe ve Finansman Dergisi, 509-26. [CrossRef]

Kuzmina, M. S. 2016. Uchet Zatrat, Kalkulirovanie i Byudzhetirovanie v Otraslyakh Proizvodstvennoi Sfery [Costing, Calculation and Budgeting in Manufacturing Industries]. Moscow: KNORUS.

Limitovskii, M. A. 2017. Investitsionnye Proekty i Realnye Optsiony Na Razvivayushchikhsya Rynkakh [Investment Projects and Real Options in Emerging Markets]. Moscow: Urait Publishing House.

Mahdiraji, Hannan Amoozad, Maryam Sedigh, Seyed Hossein Razavi Hajiagha, Jose Arturo Garza-Reyes, Vahid Jafari-Sadeghi, and Leo-Paul Dana. 2021. A novel time, cost, quality and risk tradeoff model with a knowledge-based hesitant fuzzy information: An R\&D project application. Journal Technological Forecasting and Social Change 172: 121068. [CrossRef]

Mandel, I. D. 1988. Klasternyi Analiz [Cluster Analysis]. Moscow: Finansy i statistika.

McGrath, Rita Gunther. 1997. A Real Options Logic for Initiating Technology Positioning Investments. Academy of Management Review 22: 974-96. [CrossRef]

Meerovich, M., and L. Shragina. 2018. Tekhnologiya Tvorcheskogo Myshleniya [Technology of Creative Thinking]. Moscow: Alpina.

Mizikovskii, I. E., and S. A. Pivkin. 2013. Sovershenstvovanie Metodiki Kalkulirovaniya Proektnoi Sebestoimosti Produktsii Sudostroeniya [Enhancement of the Method of Project Cost Calculation in Shipbuilding]. Vestnik Nizhegorodskogo Universiteta Im. N. I. Lo-Bachevskogo 1: 238-40.

Mogilko, D. Iu. 2019a. Funktsionalno-Stoimostnoi Analiz Biznes-Protsessov [Value Engineering of Business Processes]. Menedzhment Kachestva 2: 23-35.

Mogilko, D. Iu. 2019b. Upravlenie Proektami Razvitiya: Model Protsessa i Kompetentsii [Managing Development Projects: Proces Model and Competences]. Menedzhment Kachestva 7.

Muzyko, E. I. 2011. Analiz Razvitiya Traktovki Ekonomicheskoi Sushchnosti Kategorii ‘Realnyi Optsion’ [Evolutionary Analysis of Inter-Pretations of the Economic Essence of 'Real Options']. Ekonomicheskii Analiz: Teoriya i Praktika 36: 12-17.

Muzyko, E. I., and M. P. Maslov. 2015. Sovremennye Metody Analiza Innovatsionnykh Proektov [Modern Methods of Analysis of Innovation Projects]. Idei i Idealy 4: 112-18.

Myers, Stewart C. 1987. Finance Theory and Financial Strategy. Midland Corporate Finance Journal 5: 6-13. [CrossRef]

Nedosekin, A. O. 2003. Metodologicheskie Osnovy Modelirovaniya Finansovoi Deyatelnosti s Ispolzovaniem NechetkoMnozhestvennykh Opisanii [Methodological Foundations of Financial Modeling with the Use of Fuzzy Descriptions]. Available online: http:/ / www.mirkin.ru/_docs/doctor005.pdf (accessed on 10 September 2021).

Orlov, E. V. 2015a. Ispolzovanie Metoda Ucheta Life Cycle Costing v Tselyakh Kalkulirovaniya Zatrat [Use of Life Cycle Costing Method in Cost Calculation]. Vestnik Universiteta (State University of Management, GUU) 7: 188-93.

Orlov, E. V. 2015b. Perspektivy Primeneniya Metoda «Target Costing» Dlya Ucheta Zatrat v Aviatsionnoi Otrasli [Potential of Target Costing for Cos Accounting in Aviation Industry]. Vestnik Universiteta (State University of Management, GUU) 11: $215-19$.

Panchenko, V. V., and A. A. Abrakhmanov. 2014. Metody Otsenki Effektivnosti Innovatsion-Nykh Proektov s Primeneniem Realnykh Optsionov [Real Options-Based Methods of Analysis of Innovation Projects]. Rossiiskoe Predprinimatelstvo 10: 48-57.

Pchelkina, E., and A. Kislov. 2018. Zadachi Dlya Izuchayushchikh TRIZ [Problem Book for Students of Theory of Inventive Problem Solving]. Moscow: Galaktika.

Poliakov, A. 2017. Stati Zatrat i Elementy Zatrat [Items and Elements of Costs]. Infostat. Available online: https://infostart.ru/1c/ articles/706320 (accessed on 10 September 2021).

Porkhun, E. Iu. 2011. Vozmozhnost Primeneniya Modelei «spin-Off» i «spin-Aut» Pri Organizatsii Innovatsionnykh Kompanii [Potential of Using Spin-off and Spin-out Models in Setting up Innovation Companies]. Kreativnaya Ekonomika 5: 104.

Proektirovanie Tovarov i Uslug [Product and Service Design]. 2020. Aniri.Flatrate.Ru. Available online: http://aniri.flatrate.ru/Reading/ Reading/Me\%D0\%BDe\%D0\%B4\%D0\%B6\%D0\%BCe\%D0\%BD\%D1\%82.2020/12-ORM-2.pdf (accessed on 10 September 2021).

Robinson, Robinson, Chariri Anis, and Jatmiko Wahyu Prabowo Tri. 2018. The Role of Risk Management on Budget Quality and Slack. Academy of Accounting and Financial Studies Journal 22: 1-12.

Rogova, E. M., and A. I. Iarygin. 2010. Primenenie Novykh Metodov Otsenki Innovatsionnykh Proektov: Model Vzveshennoi Polinomialnoi Stoimosti Realnogo Optsiona [New Methods of Innovative Projects Assessment: Model of the Weighted Polynomial Value of a Real Option]. Moscow: National Research University Higher School of Economics (NRU HSE).

Rogulenko, T. M., and O. A. Smoliakov. 2019. Otsenka Tekhniko-Ekonomicheskoi Effektivno-Sti Na Baze Pokazatelya Pryamykh Eksplu-Atatsionnykh Raskhodov Kak Instrument Prinyatiya Upravlencheskikh Reshenii [Technical and Economic Performance Analysis Based on Direct Operational Costs as an Instrument O]. In Accounting Anc Control and Analytical Processes in the Context of Economic Digitalisation. Moscow: KNORUS, pp. 320-24.

Rosenberger, J. 2003. What Are Real Options? A Review of Empirical Research. Seattle: Academy of Management.

Rutkowska-Ziarko, A., and L. Markowski. 2020. Market and Accounting Risk Factors of Asset Pricing in the Classical and Downside Approaches. Annales Universitatis Mariae Curie-Skłodowska, Sectio H-Oeconomia 54: 103-12. [CrossRef]

Ryzhova, V. V., ed. 2019. Primenenie Funktsionalno-Stoimostnogo Analiza v Reshenii Upravlencheskikh Zadach [Application of Value Engineering in Man-Agerial Problems]. Moscow: INFRA-M. 
Savinykh, V. P., and V. Ia. Tsvetkov. 2001. Geoinformatsionnyi Analiz Dannykh Distantsionnogo Zondirovaniya [Geoinformational Data Analysis for Distance Sounding]. Moscow: Kartotsentr-Geodezizda.

Shcherbakov, A. V., and E. A. Prikhodko. 2003. Osnovy Finansovogo Funktsionalno-Stoimostnogo Analiza [Fundamentals of Value EngiNeering]. Novosibirsk: NSTU Publishing House.

Sokolova, A. P., and D. V. Bondareva. 2019. Upravlenie riskami innovacionnyh proektov [Risk management of innovative projects]. Vestnik Altajskoj Akademii Ekonomiki i Prava [Bulletin of Altai Academy of Economics and Law] 5: 148-57.

Telekhov, I. I. 2017. Vstroennye Realnye Optsiony v Otsenke i Analize Innovatsion-Nykh Proektov [Embedded Real Options in the Analysis of Innovation Projects]. Saint Petersburg: Saint Petersburg State University.

Terenteva, Z. S., and I. A. Khalizova. 2019. Gibkie Metody Upravleniya Proektami, Analiz i Sravnenie [Flexible Methods of Project Management, Analysis and Comparison]. Azimut Nauchnykh Issledovanii: Ekonomika i Upravlenie 8: 374-76.

Tiurin, A. G., and I. O. Zuev. 2014. Klasternyi Analiz, Metody i Algoritmy Klasterizatsii [Cluster Analysis, Clusterisation Methods and Algo-Rithms]. Herald of Mstu Mirea 3: 86.

Troshin, Aleksandr Nikolaevich, Anna Anatolievna Burdina, Nataliya Valerievna Moskvicheva, Elena Nikolaevna Nikulina, Elena Vladimirovna Tarasova, and Tatiana Mikhailovna Rogulenko. 2016. Mechanism to Analyze Economic Reliability of the Innovational Potential of Aircraft Enterprises. International Journal of Applied Business and Economic Research 14: 747-65.

Uyar, M. 2018. Evaluation of the Relationship between Management Accounting System, Risk Management and Company Performance by Using Structural Equation Model. İsletme Araştırmaları Dergisi Journal of Business Research-Turk 10: 144-72. [CrossRef]

Voronova, E. Iu. 2014. Metod Target-Kosting Kalkulirovaniya Sebestoimosti [Methods of Target Costing]. Auditorskiye Vedomosti 9: 83-96.

Whitney, Patrick. 2015. Design and the Economy of Choice. She Ji: The Journal of Design, Economics, and Innovation 1: 58-80. [CrossRef]

Yau-Yeung, Daisy, Ogan Yigitbasioglu, and Peter Green. 2020. Cloud accounting risks and mitigation strategies: Evidence from Australia. In Accounting Forum. London: Routledge, vol. 44, pp. 421-46. [CrossRef]

Za Chestnyi Biznes. 2018. Financial Statements of Solinov Research Institute of Technical Glass, AO. Available online: https:// zachestnyibiznes.ru/company/ul/1027700034680_7727059017_AO-NITS-IM-VFSOLINOVA/balance (accessed on 10 September 2021).

Za Chestnyi Biznes. 2019a. Financial Statements of the Myasishchev Design Bureau, AO. Available online: https:/ / zachestnyibiznes. ru/company/ul/1105040001549_5040097816_AO-EMZ-IM-V-M-MYaSISchEVA/balance (accessed on 10 September 2021).

Za Chestnyi Biznes. 2019b. Financial Statements of the Baranov Central Institute of Aviation Motors, Federal State Unitary Enterprise. Available online: https: / zachestnyibiznes.ru/company/ul/1027700574505_7722016820_FGUP-CIAM-IM-PI-BARANOVA/ balance (accessed on 10 September 2021).

Zonova, A. V. 2009. Novoe Napravlenie Razvitiya Dvoinoi Zapisi [New Line of Development of Double-Entry Accounting]. Bukhgalter i Zakon 3: 8-21.

Zonova, A. V. 2017. Kak Prinimat Upravlencheskie Resheniya Na Osnove Analiza Finansovoi Otchetnosti [How to Make Managerial Deci-Sions Based on Analysis of Financial Statements]. Molodoy Ucheniy 7: 82-86. 